\title{
Structure of asparagine-linked oligosaccharides of an aspartic proteinase from the zygomycete fungus Rhizomucor pusillus
}

\author{
Kohji Murakami,† Kyoko Takeuchi, $\neq$ Teruhiko Beppu $₫$ \\ and Sueharu Horinouchi
}

Department of Biotechnology, Graduate School of Agriculture and Life Sciences, The University of Tokyo, Yayoi 1-1-1, Bunkyo-ku, Tokyo 113, Japan
Author for correspondence: Sueharu Horinouchi Tel: +8133812 2111, ext. 5123. Fax: +8135802 2931. e-mail: asuhori@hongo.ecc.u-tokyo.ac.jp

\begin{abstract}
The zygomycete fungus Rhizomucor pusillus (previously called Mucor pusillus) secretes an aspartic proteinase containing two asparagine-linked, highmannose type oligosaccharide chains at Asn'9 and Asn ${ }^{188}$. For structural elucidation of the carbohydrate moieties, the protein was divided into two portions, an N-terminal portion containing Asn ${ }^{79}$ and a C-terminal portion containing Asn ${ }^{188}$, by a specific autocatalytic cleavage under alkaline conditions. Each of the asparagine-linked oligosaccharides was then released by peptide- $N$-glycosidase $F$ digestion and pyridylaminated with a fluorescent reagent, 2-aminopyridine, at the reducing end. High-performance liquid chromatography analyses showed that the structure of the asparagine-linked oligosaccharide chain attached to residue Asn'9 was Man GlcNAc $_{2}$, and that bound to residue Asn ${ }^{188}$ was Man $_{5}$ GICNAC $_{2}$ and Man $_{6}$ GICNAC $_{2}$. These observations suggest that the processing of mannose residues in asparaginelinked oligosaccharides in the Golgi apparatus of Rhizomucor resembles that in mammalian cells.
\end{abstract}

Keywords: asparagine-linked oligosaccharide, Rbizomucor pusillus, zygomycete, aspartic proteinase

\section{INTRODUCTION}

The zygomycete fungus Rhizomucor pusillus (previously called Mucor pusillus) secretes a characteristic aspartic proteinase with high milk-clotting activity along with relatively low proteolytic activity (Arima $e t$ al., 1967, 1968). This proteinase, called $R$. pusillus pepsin (MPP), is widely used as a milk coagulant in industrial cheese production. We previously reported the cloning and sequencing of the MPP structural gene from R. pusillus IFO4578 (Tonouchi et al., 1986) and its expression in Saccharomyces cerevisiae (Yamashita et al., 1987) and Aspergillus oryzae (Murakami et al.,

†Present address: Research Division, The Green Cross Corporation, Hirakata-shi, Osaka 573, Japan.

‡Present address: Tokyo Research Laboratories, Kyowa Hakko Kogyo Co., Machida-shi, Tokyo 194, Japan.

SPresent address: Department of Applied Biological Science, College of Bioresource Sciences, Nihon University, Fujisawa-shi, Kanagawa 252, Japan.

Abbreviations: PA, pyridylaminated; MPP, R. pusillus pepsin; Endo $H$, endo- $\beta$ - $N$-acetylglucosaminidase $H$; PNGase $F$, peptide- $N$-glycosidase $F$; GU, glucose unit.
1993). Studies with these heterologous expression systems revealed that two asparagine residues, $\mathrm{Asn}^{79}$ and $\mathrm{Asn}^{188}$, among the three possible $\mathrm{N}$-linked glycosylation sites (Asn ${ }^{79}$-Ile-Thr, Asn ${ }^{113}$-Val-Ser and Asn ${ }^{188}$. Asn-Thr in MPP) were actually glycosylated in $S$. cerevisiae (Aikawa et al., 1990) and A. oryzae (Murakami et al., 1993). In addition, we found that the MPPs produced by both recombinant $S$. cerevisiae (Aikawa $e t$ al., 1990) and A. oryzae (Murakami et al., 1993) were more glycosylated than that produced by $R$. pusillus due to different processing of mannose residues. The extra mannosylation of MPPs caused a decrease in milkclotting activity along with an increase in proteolytic activity. Furthermore, deglycosylation of MPP by glycosidase treatment or by amino acid replacement of the glycosylation sites caused an increase in milk-clotting activity along with a decrease in proteolytic activity (Murakami et al., 1993). The glycosylation of MPP thus causes distinct modulation of the enzymic properties, which indicates the functional importance of $N$-linked oligosaccharide chains of MPP. In addition to the effect of $N$-linked glycosylation on the properties of this industrially important enzyme, a slight difference in 
processing of $\mathrm{N}$-linked glycans among various organisms, and even among the filamentous fungi, prompted us to determine the structure of $\mathrm{N}$-linked oligosaccharides in MPP. In the present study we have characterized the carbohydrate moieties of MPP produced by R. pusillus IFO4578.

\section{METHODS}

Purification of MPPs. MPPs from $R$. pusillus strains IFO4578 and F27 were purified as previously described (Murakami et al., 1993, 1994). Endo- $\beta$ - $N$-acetylglucosaminidase $\mathrm{H}$ (Endo $\mathrm{H}$; Seikagaku Kogyo)-treated MPP and recombinant yeast MPPs were purified as previously described (Aikawa et al., 1990). Protein content of the purified MPP samples was estimated by measuring their absorbance at $280 \mathrm{~nm}$ with $A_{1 \mathrm{~cm}}^{1 \%}=10$ (Arima et al., 1968). Purified MPP was digested with Endo $\mathrm{H}$ and peptide-N-glycosidase F (PNGase F) (Takara Shuzo) by the method of Tarentino et al. (1974) and Chu (1986), respectively.

Carbohydrate composition. Purified MPP was hydrolysed at $100^{\circ} \mathrm{C}$ for $12 \mathrm{~h}$ in $2.5 \mathrm{M}$ trifluoroacetic acid. Carbohydrate compositions were determined by high-pH anion-exchange chromatography with a pulsed amperometric detection system (Dionex BioLC) (Hardy et al., 1988). Mannose (Man), Nacetylglucosamine (GlcNAc), N-acetylgalactosamine (GalNAc), fucose and galactose can be measured by this method.

N-terminal amino acid sequencing. Purified MPP was subjected to automated Edman degradation on an Applied Biosystems gas-phase sequencer equipped with an on-line amino acid phenylthiohydantoin analyser.

Pyridylamination. The oligosaccharides released from glycopeptides by PNGase F digestion were labelled with 2aminopyridine by using a commercially available reagent kit (Takara Shuzo). The pyridylaminated derivatives (PA-oligosaccharides) were purified by Sephadex G-15 column chromatography.

High-performance liquid chromatography. PA-oligosaccharides were separated by HPLC using a chromatography system equipped with a fluorescence spectromonitor (Shimadzu, RF-550). For size-fractionation HPLC, PAoligosaccharides were loaded onto a TSK gel amide- 80 column $(0.46 \times 25 \mathrm{~cm}$, Tosoh Corp.) equilibrated with a mixture of $3 \%$ acetic acid/triethylamine buffer $(\mathrm{pH} \mathrm{7.3)}$ and acetonitrile $(35: 65, \mathrm{v} / \mathrm{v})$. The column was eluted at a flow rate of $1.0 \mathrm{ml} \mathrm{min}-1$ at $40^{\circ} \mathrm{C}$ by increasing the ratio of acetic acid/triethylamine buffer to acetonitrile from $35: 65$ to $50: 50$ over $60 \mathrm{~min}$.

The reverse-phase HPLC was performed with a Nakanopak ODS-A column $(6 \times 150 \mathrm{~mm})$ equilibrated with $10 \mathrm{mM}$ sodium phosphate buffer $(\mathrm{pH} 3.8$ ) containing $0.1 \%$ 1-butanol. The column was eluted at a flow rate of $1.0 \mathrm{ml} \mathrm{min}^{-1}$ at $55^{\circ} \mathrm{C}$ by linearly increasing the 1-butanol concentration from $0.1 \%$ to $0.25 \%$ over $60 \mathrm{~min}$. PA-oligosaccharides were detected by fluorescence using the excitation and emission wavelengths of 320 and $400 \mathrm{~nm}$ respectively. The glucose units were determined by comparing the retention time of each PAoligosaccharide on both columns with those of the standard PA-glucose oligomers (Takara Shuzo) and plotting on a twodimensional sugar map according to the method of Tomiya $e t$ al. (1988).

Partial acetolysis was carried out by the method of Hase $e t$ al . (1985). The partial acetolysates obtained from the PAoligosaccharides as well as the standard oligomannose-type oligosaccharides (Takara Shuzo) were analysed by sizefractionation HPLC.

\section{RESULTS}

\section{Carbohydrate composition of MPP}

MPP contains two sugar chains at $\mathrm{Asn}^{79}$ and $\mathrm{Asn}^{188}$ (Aikawa et al., 1990). Our previous studies using the MPP gene (Tonouchi et al., 1986) in the hosts Saccharomyces cerevisiae (Aikawa et al., 1990) and Aspergillus oryzae (Murakami et al., 1993) showed that MPP also contains two high-mannose-type glycans at the same asparagine residues. To examine the presence of $\mathrm{O}$ linked glycosylation in MPP in R. pusillus IFO4578, we removed the two $\mathrm{N}$-linked oligosaccharides by Endo $\mathrm{H}$ treatment and prepared the protein by Mono $Q$ anionexchange column chromatography followed by Superose 12 gel-filtration column chromatography as described previously (Aikawa et al., 1990). We then analysed the carbohydrate composition of the Endo Htreated MPP. Native MPP produced by strain IFO4578 contained nearly four ( $4.4 \mathrm{~mol}$ per mol protein) GlcNAc and ten $(9.8 \mathrm{~mol}$ per mol protein) mannose residues, consistent with the previous data (Murakami et al., 1994). On the other hand, the Endo H-treated MPP contained nearly two (2.3 mol per mol protein) GlcNAc residues and no mannose residues. Other sugars such as fucose, galactose and GalNAc were not detected in either the native or Endo H-treated MPP. These data show that MPP produced by $R$. pusillus IFO4578 contains two high-mannose-type glycans and no $O$ linked oligosaccharides.

\section{Autocatalytic digestion of MPP}

To analyse the Asn ${ }^{79}$-linked and $\mathrm{Asn}^{188}$-linked oligosaccharide chains separately, we first tried to digest the MPP protein produced by $R$. pusillus IFO4578 with restriction proteinases, such as arginyl-endopeptidase and lysyl-endopeptidase, to obtain peptides containing one of the two sugar chains. This approach did not give good separation of fragments. However, during these studies, we found that MPP was autocatalytically digested into two glycopeptides when concentrated MPP $\left(1 \mathrm{mg} \mathrm{ml}^{-1}\right)$ was incubated at $37^{\circ} \mathrm{C}$ for $12 \mathrm{~h}$ in $100 \mathrm{mM}$ Tris/ $\mathrm{HCl}$ buffer, $\mathrm{pH} 8 \cdot 0$. The autocatalytic cleavage of MPP also occurred with MPPs produced by the recombinant yeast and with the Endo H-digested MPP produced by $R$. pusillus under the same conditions (Fig. 1a). The glycosylation of MPP in two different $R$. pusillus strains, IFO4578 and F27, was assumed to be the same since the sizes of undigested MPP and digested fragments were the same.

To determine whether each of the two autolysed fragments contained a sugar chain, we further investigated these two glycopeptides by using MPPs produced by the recombinant yeast as references, because these were easily obtained in large quantities. The mutated MPPs used were: $79 \mathrm{Q}$, in which one $\left(\mathrm{Asn}^{79}\right)$ of the glycosylation sites was replaced by $G \ln ; 188 \mathrm{Q}$, in which one $\left(\mathrm{Asn}^{188}\right)$ of the two glycosylation sites was replaced 
(b)

(a)

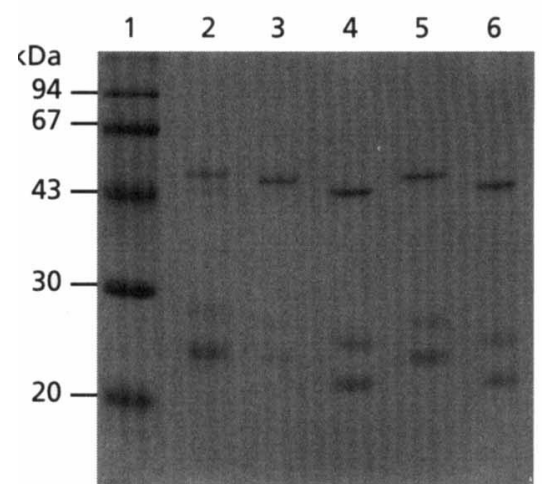

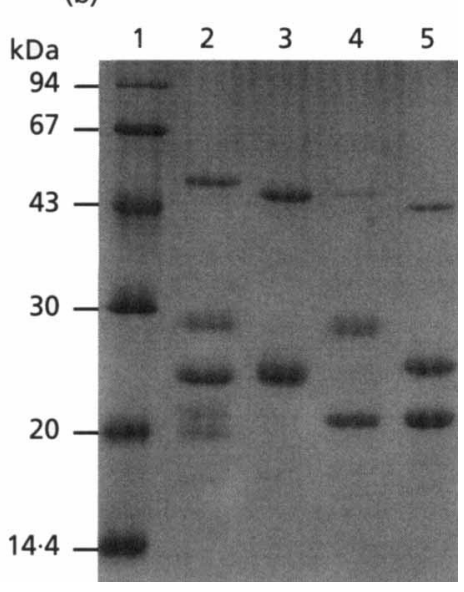

Fig. 1. Autocatalytic digestion of MPPs produced by recombinant yeast and $R$. pusillus (a) and mutated MPPs produced by recombinant yeast (b). (a) Each purified MPP $\left(1 \mathrm{mg} \mathrm{ml}^{-1}\right.$ in $100 \mathrm{mM}$ Tris/ $/ \mathrm{HCl}, \mathrm{pH} \mathrm{8.0)}$ was incubated at $37^{\circ} \mathrm{C}$ for $12 \mathrm{~h}$ and subjected to SDS-PAGE. Gels contained $1 \mu \mathrm{g}$ protein per track, $12.5 \%$ acrylamide gels were stained with Coomassie brilliant blue R250. In addition to undigested MPP (43-46 kDa in size) in each lane, two autolysed fragments (between 22 and $28 \mathrm{kDa}$ ) are seen. Lane 1, size markers; lane 2, yeast MPP; lane 3, F27 MPP; lane 4, F27 MPP (Endo $H$ treated); lane 5, IFO4578 MPP; lane 6, IFO4578 MPP (Endo $\mathrm{H}$ treated). (b) The mutated MPPs $\left(1 \mathrm{mg} \mathrm{ml}^{-1}\right.$ in $100 \mathrm{mM}$ Tris $/ \mathrm{HCl}, \mathrm{pH} \mathrm{8.0)}$ were autodigested and subjected to SDS-PAGE as in (a). Lane 1, size markers; lane 2, yeast MPP (native); lane 3, yeast MPP (79Q); lane 4, yeast MPP (188Q); lane 5, yeast MPP (79Q188Q).

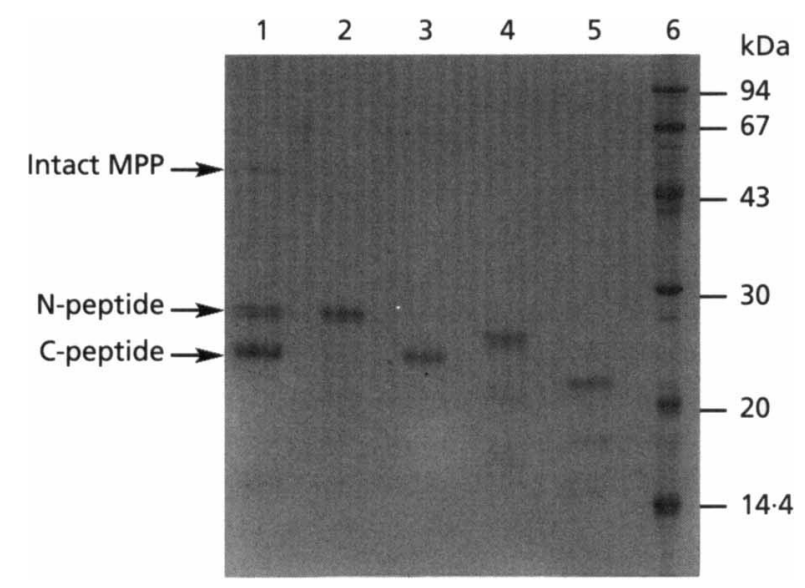

Fig. 2. Purification of $\mathrm{N}$ - and C-peptides of MPP produced by $R$. pusillus IFO4578. Both purified peptides and PNGase F-digested peptides were subjected to SDS-PAGE. Gels contained $1 \mu \mathrm{g}$ protein per track, $12.5 \%$ acrylamide gels were stained with Coomassie brilliant blue R250. Lane 1, IFO4578 MPP (autolysed at pH 8); lane 2, N-peptide; lane 3, C-peptide; lane 4, $\mathrm{N}$-peptide (PNGase F digested); lane 5, C-peptide (PNGase F digested); lane 6 , size markers.

by $\mathrm{Gln}$; and 79Q188Q, in which both Asn residues were replaced by $G \ln$. These were autocatalytically digested into two glycopeptides under alkaline conditions, as determined by SDS-PAGE (Fig. 1b). Comparison of the autolysed patterns of native MPP and $79 \mathrm{Q}$ predicted that the $28 \mathrm{kDa}$ band ( $\mathrm{N}$-peptide) derived from native MPP contained a sugar chain attached to $\mathrm{Asn}^{79}$. Similarly, the $22 \mathrm{kDa}$ glycopeptide (C-peptide) was predicted to contain the Asn ${ }^{188}$-linked oligosaccharide chain.

\section{Isolation of glycopeptides from MPP}

We purified the two glycopeptides (N-peptide and Cpeptide) by Mono $Q$ anion-exchange column chromatography followed by Superose 12 gel-filtration

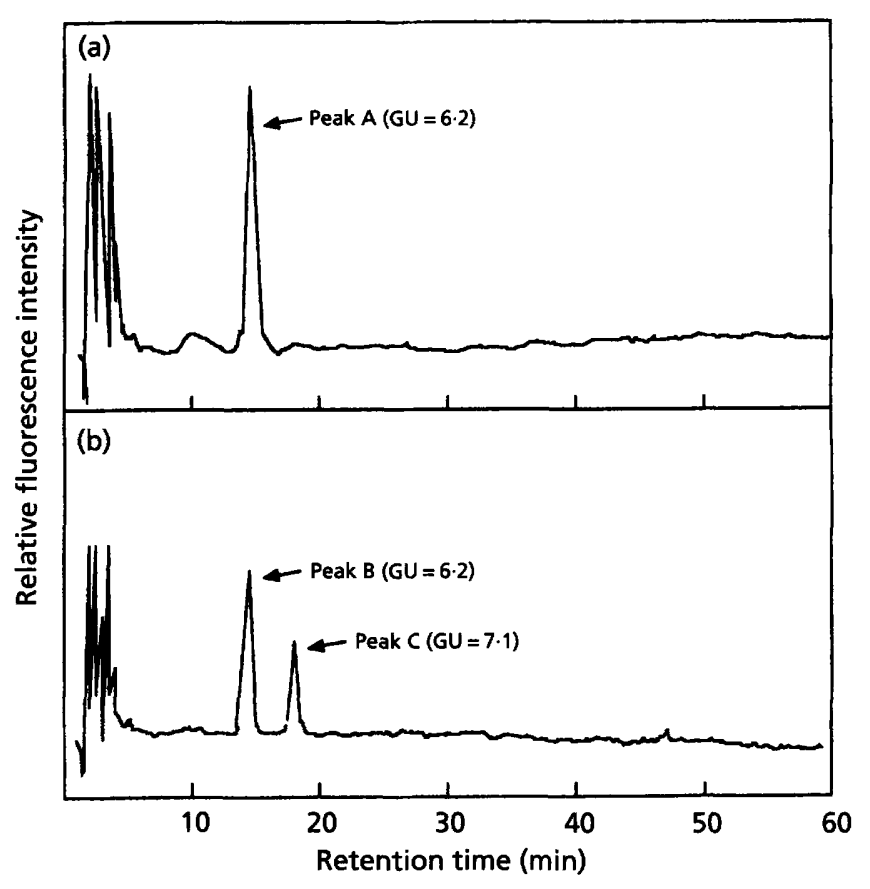

Fig. 3. Size-fractionation HPLC of PA-oligosaccharides from the $\mathrm{N}$-peptide (a) and the C-peptide (b). GUs were determined using a PA-oligomer mixture as the standard.

column chromatography. The purified glycopeptides and the peptides deglycosylated with PNGase F were analysed by SDS-PAGE (Fig. 2). We determined the Nterminal amino acid sequence of both glycopeptides and found that N-peptide had the sequence Ala-Glu-GlyAsp-Gly, which was identical to the $\mathrm{N}$-terminal amino acid sequence of the mature MPP produced by $R$. pusillus IFO4578 (Hiramatsu et al., 1991). On the other hand, the C-peptide gave two $\mathrm{N}$-terminal amino acid sequences, Ser ${ }^{170}$-Val-Tyr-Met-Asn and $\mathrm{Met}^{173}$-AsnTyr-Asn-Asp, which showed that MPP can be cleaved at 


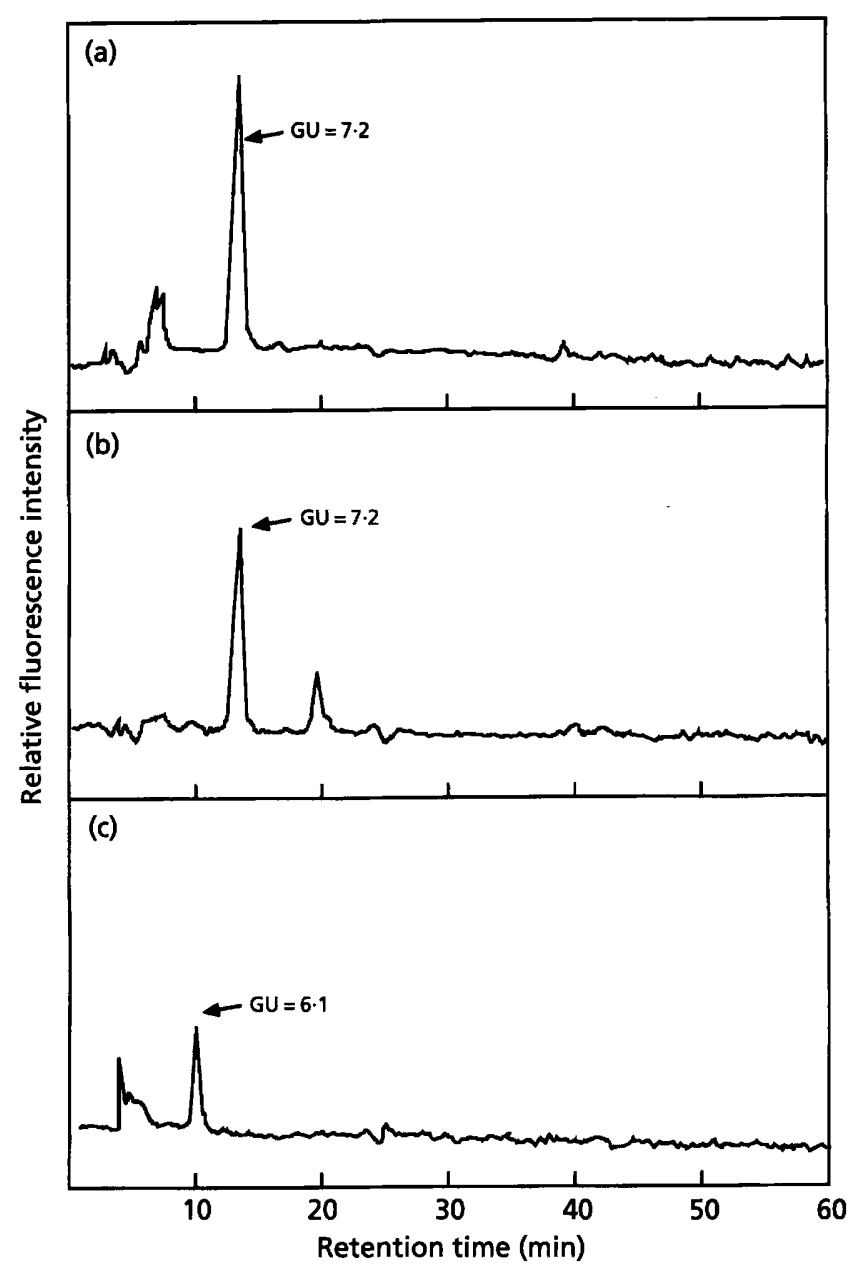

Fig. 4. Reverse-phase HPLC of peaks A (a), B (b) and C (c) obtained by size-fractionation HPLC. Peak $A$ is derived from the $\mathrm{N}$-peptide, peaks $\mathrm{B}$ and $\mathrm{C}$ are derived from the C-peptide. GUs were determined using a PA-oligomer mixture as the standard.

two sites, between $\mathrm{Phe}^{169}$ and $\mathrm{Ser}^{170}$ and between $\mathrm{Tyr}^{172}$ and $\mathrm{Met}^{173}$.

\section{Structural analysis of the sugar chains in MPP}

To elucidate the structure of the asparagine-linked oligosaccharide chains of MPP, the oligosaccharides were released from each of the $\mathrm{N}$ - and C-peptides by PNGase $\mathrm{F}$ digestion and modified by 2 -aminopyridine at the reducing ends. Fig. 3 shows the elution profiles of PA-oligosaccharides from an amide silica column. The $\mathrm{PA}$-oligosaccharides derived from the $\mathrm{N}$-peptide showed a single peak (peak A) on size-fractionation HPLC (Fig. 3a). The PA-oligosaccharide in peak A showed a single peak on reverse-phase HPLC, which demonstrated the presence of a single component (Fig. 4). The glucose unit (GU) value was determined by comparing the retention time of peak A with those of the standard PA-glucose oligomers (Takara Shuzo). From the GU value of peak A on both the size-fractionation $(G U=6 \cdot 2)$ and the reverse-phase HPLC $(\mathrm{GU}=7 \cdot 2)$, plotted on a two- (a) $\mathrm{Man}_{5} \mathrm{GlCNAC}_{2}$

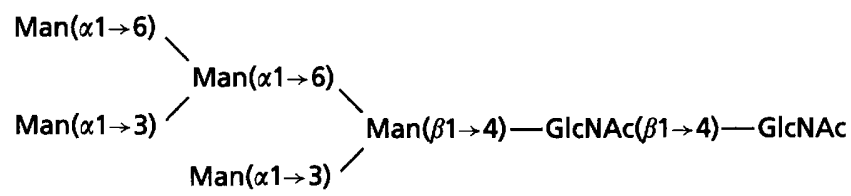

(b) $\mathrm{Man}_{6} \mathrm{GlCNAC}_{2}$

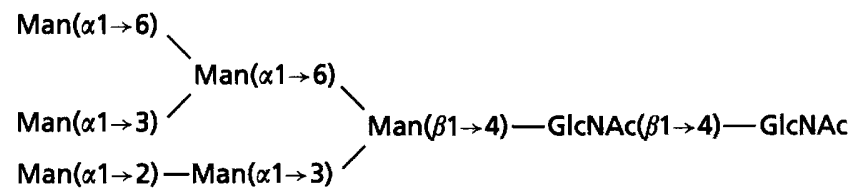

Fig. 5. Structures of the standard PA-oligosaccharides, $\mathrm{Man}_{5} \mathrm{GlCNAC}_{2}$ (a) and $\mathrm{Man}_{5} \mathrm{GICNAC}_{2}$ (b), used as references for determination of $\mathrm{GU}$ values.

dimensional sugar map according to the method of Tomiya et al. (1988), the PA-oligosaccharide from the $\mathrm{N}$-peptide corresponds to $\mathrm{Man}_{5} \mathrm{GlcNAc}_{2}-\mathrm{PA}$. Furthermore, the elution position of peak $A$ on both columns was the same as that of the standard oligomannose-type oligosaccharide, $\operatorname{Man}_{5}$ GlcNAc$_{2}-\mathrm{PA}$. On the other hand, the PA-oligosaccharides from the C-peptide showed two major peaks [peaks $B(G U=6 \cdot 2)$ and $C(G U=7 \cdot 1)$ ] on size-fractionation HPLC (Fig. 3b). These two peaks were collected as separate fractions and analysed by reverse-phase HPLC (Fig. 4). The GU values of peaks B and $C$ on both the size-fractionation and reverse-phase HPLC were identical to that of $\mathrm{Man}_{5} \mathrm{GlcNAc}_{2}-\mathrm{PA}$ and $\mathrm{Man}_{6} \mathrm{GlcNAc}_{2}-\mathrm{PA}$ respectively. The elution positions of peak $B$ and $C$ were the same as those of standard oligomannose-type oligosaccharides $\mathrm{Man}_{5} \mathrm{GlcNAc}_{2}-\mathrm{PA}$ and $\mathrm{Man}_{6} \mathrm{GlcNAc}_{2}-\mathrm{PA}$, respectively. The structures of the standard oligosaccharides are shown in Fig. 5. In addition, digestion of the PA-oligosaccharides eluted in peaks $B$ and $C$ by $\alpha$-mannosidase yielded a new peak which appeared at the elution position of $\mathrm{Man}_{1} \mathrm{GlcNAc}_{2}$-PA on both reverse-phase and sizefractionation HPLC (data not shown).

The oligosaccharides in peak $A$ and peak $C$ on the reverse-phase HPLC (Fig. 4) were collected and further analysed by partial acetolysis. The fraction of the acetolysis product containing the reducing end residue from peak $A$, as well as a standard oligomannose-type oligosaccharide, $\mathrm{Man}_{5} \mathrm{GlcNAc}_{2}-\mathrm{PA}$, were analysed by size-fractionation HPLC. The partial acetolysate obtained from peak A gave two major peaks, M2 and M4 (Fig. 6a, b). M2 and M4 corresponded to a tetrasaccharide and a hexasaccharide respectively, the retention times of which were identical to those of the partial acetolysate obtained from the standard oligosaccharide $\mathrm{Man}_{5} \mathrm{GlcNAc}_{2}$-PA (Fig. 5). The structures of sugars in peak M2 and M4 were thus assumed to be Man $\alpha 1-3 \mathrm{Man} \beta 1-4 \mathrm{GlcNAc}_{2}$-PA and Man $\alpha 1-3 \mathrm{Man} \alpha 1-$ 6(Man $\alpha 1-3)$ Man $\beta 1-4 \mathrm{GlCNAc}_{2}$-PA respectively. The partial acetolysates obtained from peak $C$ yielded two 


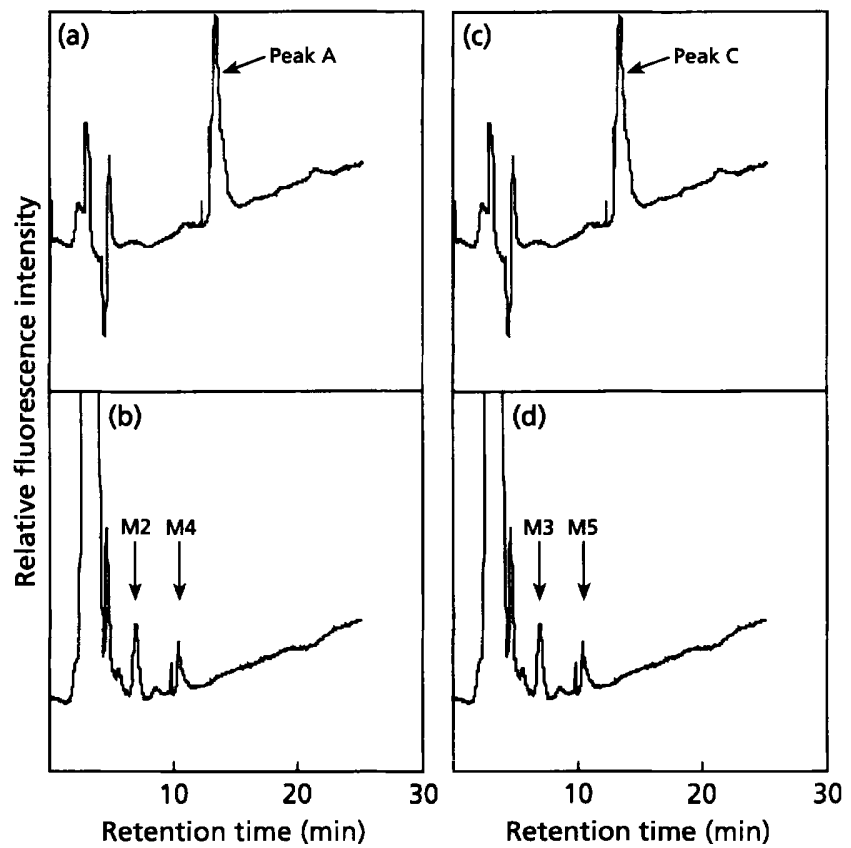

Fig. 6. Size-fractionation HPLC of PA-oligosaccharide products derived from peaks $A$ and $C$ of fig. 4 by partial acetolysis. (a) PA-oligosaccharide obtained from peak A of fig. 4. (b) Partial acetolysates of PA-oligosaccharides obtained from peak $A$. (c) PA-oligosaccharide obtained from peak C. (d) Partial acetolysates of PA-oligosaccharides obtained from peak $C$.

major peaks, M3 and M5 (Fig. 6c, d). M3 and M5 showed sizes corresponding to a pentasaccharide and a heptasaccharide, respectively, the elution positions of which were identical to those from the standard oligosaccharide $\mathrm{Man}_{6} \mathrm{GlcNAc}_{2}$-PA (Fig. 5). The sugars in peaks $\mathrm{M} 3$ and $\mathrm{M} 5$ were therefore assumed to be Man $\alpha 1-2 M a n \alpha 1-3 \mathrm{Man} \beta 1-4 \mathrm{GlcNAc}-\mathrm{PA}$ and Man $\alpha 1-$ 3 Man $\alpha 1-6$ (Man $\alpha 1-2 \mathrm{Man} \alpha 1-3) \mathrm{Man} \beta 1-4 \mathrm{GlCNAc}_{2}-\mathrm{PA}$ respectively. All of these data indicate that the $N$-linked oligosaccharide chain bound to residue $A_{s n}{ }^{79}$ was $\mathrm{Man}_{5} \mathrm{GlcNAc}_{2}$ and that bound to residue $\mathrm{Asn}^{188}$ was $\mathrm{Man}_{5} \mathrm{GlcNAc}_{2}$ and $\mathrm{Man}_{6} \mathrm{GlcNAc}_{2}$.

\section{DISCUSSION}

In this study, we characterized the carbohydrate moiety of MPP produced by $R$. pusillus IFO4578. Consistent with the carbohydrate composition of MPP, $\mathrm{Asn}^{79}$ was found to bind a sugar chain of $\mathrm{Man}_{5} \mathrm{GlcNAc}_{2}$ and $\mathrm{Asn}^{188}$ was found to bind two different sugar chains of $\mathrm{Man}_{5} \mathrm{GlcNAc}_{2}$ and $\mathrm{Man}_{6} \mathrm{GlcNAc}_{2}$. The synthesis of the $N$-linked oligosaccharide precursor $\left(\mathrm{Glc}_{3} \mathrm{Man}_{9} \mathrm{GlcNAc}_{2}\right.$-dolichol) and the initial processing of the oligosaccharide in the endoplasmic reticulum are similar in fungi and most other eukaryotes (Kukuruzinska et al., 1987), while the later trimming steps in the Golgi apparatus are different. Our preliminary analysis using oligosaccharide processing inhibitors, such as castanospermine, 1-deoxynojirimycin and $\mathrm{N}$ methyldeoxynojirimycin, suggest that a sugar chain larger than $\mathrm{Man}_{5-6} \mathrm{GlcNAc}_{2}$ is transferred to MPP in
$R$. pusillus, because MPP accumulated in the presence of these processing inhibitors had a lower mobility than mature MPP on PAGE (unpublished data). In the Golgi apparatus of mammalian cells, $\mathrm{Man}_{8} \mathrm{GlcNAc}_{2}$ is trimmed to $\mathrm{Man}_{5} \mathrm{GlcNAc}_{2}$ by Golgi $\alpha$-mannosidase I and further processed by a series of glycosidases and glycosyltransferases. On the other hand, in S. cerevisiae, $\mathrm{Man}_{8} \mathrm{GlcNAc}_{2}$ is thought to be the ultimate product of trimming (Kukuruzinska et al., 1987), suggesting that yeast lacks an enzyme like Golgi $\alpha$-mannosidase I. The processing of mannose residues in $\mathrm{N}$-linked glycans in $R$. pusillus resembles that in mammalian cells (Kornfeld \& Kornfeld, 1985), suggesting that the zygomycete fungus $R$. pusillus possesses a specific $\alpha$-mannosidase similar to the mammalian Golgi $\alpha$-mannosidase I.

We previously showed that MPP produced by the recombinant Aspergillus oryzae was more highly glycosylated than that produced in the original $R$. pusillus strain (Murakami et al., 1993), indicating that the processing of $N$-linked glycans in $A$. oryzae was different from that in R. pusillus. Salovuori et al. (1987) reported that the structures of $\mathrm{N}$-linked glycans produced by the filamentous fungus Trichoderma reesei were $\mathrm{Man}_{5} \mathrm{GlcNAc}_{2}$ and $\mathrm{Man}_{9} \mathrm{GlcNAc}_{2}$. Takegawa et al. (1989) reported that the most abundant $N$-linked glycan attached to the glucoamylase of Rhizopus niveus was $\mathrm{Man}_{8} \mathrm{GlcNAc}_{2}$. It is therefore apparent that the distribution and substrate specificity of the mannosetrimming enzymes in the Golgi apparatus are different among the filamentous fungi. The processing enzymes of filamentous fungi such as Golgi $\alpha$-mannosidase are useful for studying the processing of glycoproteins. Cloning of a processing enzyme, $\alpha$-1,2-mannosidase, from $R$. pusillus is now in progress in our laboratory.

We found that MPP was cleaved autocatalytically into two major glycopeptides under alkaline conditions. Analysis of the $\mathrm{N}$-terminal amino acid sequences of both glycopeptides identified the cleavage sites to be between Phe $^{169}-$ Ser $^{170}$ and $\mathrm{Tyr}^{172}-\mathrm{Met}^{173}$. MPP is a member of the acid protease family in which two aspartate residues are involved in the catalysis (MacKinlay \& Wake, 1971; Pitts et al., 1992). It therefore has an acidic optimum $\mathrm{pH}$ and has relatively high substrate specificity with extremely low proteolytic activity (Arima et al., 1967; Iwasaki et al., 1967). MPP, which is known to recognize aromatic amino acid residues and cleave peptide bonds at its $\mathrm{COOH}$ side, preferentially cleaves the peptide bond $\mathrm{Phe}^{105}-\mathrm{Met}^{106}$ in $\kappa$-casein and induces destabilization and clotting of $\kappa$-casein dispersed in milk (Etoh et al., 1982). Since the autocatalytic cleavage sites, between $\mathrm{Phe}^{169}-\mathrm{Ser}^{170}$ and between $\mathrm{Tyr}^{172}-\mathrm{Met}^{173}$, are similar to $\mathrm{Phe}^{\mathbf{1 0 5}}$-Met ${ }^{\mathbf{1 0 6}}$ of $\kappa$-casein, the substrate specificity of MPP may be slightly changed in some unknown way under the alkaline conditions.

\section{ACKNOWLEDGEMENTS}

This work was supported by the Grant-in-Aid for Scientific Research on Priority Areas no. 05274103 from the Ministry of Education, Science and Culture, Japan. 


\section{REFERENCES}

Aikawa, J., Yamashita, T., Nishiyama, M., Horinouchi, S. \& Beppu, T. (1990). Effect of glycosylation on the secretion and enzyme activity of Mucor rennin, an aspartic proteinase of Mucor pusillus, produced by recombinant yeast. J Biol Chem 265, 13955-13959.

Arima, K., Iwasaki, S. \& Tamura, G. (1967). Milk clotting enzyme from micro-organisms. Part I. Screening test and the identification of potent fungus. Agric Biol Chem 31, 540-545.

Arima, K., Yu, J., Iwasaki, S. \& Tamura, G. (1968). Milk-clotting enzyme from micro-organisms. V. Purification and crystallization of Mucor rennin from Mucor pusillus var. Lindt. Appl Microbiol $16,1727-1733$.

Chu, F. K. (1986). Requirements of cleavage of high mannose oligosaccharides in glycoproteins by peptide $\mathrm{N}$-glycosidase $\mathrm{F}$. $J$ Biol Chem 261, 172-177.

Etoh, Y., Shoun, H., Arima, K. \& Beppu, T. (1982). Photo-oxidation on a histidyl residue of milk-clotting acid protease, $M u c o r$ rennin. J Biochem 91, 747-753.

Hardy, N. R., Townsend, R. R. \& Lee, Y. C. (1988). Monosaccharide analysis of glycoconjugates by anion-exchange chromatography with pulsed amperometric detection. Anal Biochem 170, 54-62.

Hase, S., Kikuchi, N., Ikenaka, T. \& Inoue, K. (1985). Structures of sugar chains of the third component of human complement. J Biochem 98, 863-874.

Hiramatsu, R., Horinouchi, S., Uchida, E., Hayakawa, T. \& Beppu, T. (1991). The secretion leader of Mucor pusillus rennin which possesses an artificial Lys-Arg sequence directs secretion of mature human growth hormone by Saccharomyces cerevisiae. Appl Environ Microbiol 57, 2052-2056.

Iwasaki, S., Tamura, G. \& Arima, K. (1967). Milk clotting enzyme from micro-organisms. Part II. The enzyme production and the properties of crude enzyme. Agric Biol Chem 31, 540-545.

Kornfeld, R. \& Kornfeld, S. (1985). Assembly of asparagine-linked oligosaccharides. Annu Rev Biochem 54, 631-664.

Kukuruzinska, M. A., Bergh, M. L. E. \& Jackson, B. J. (1987). Protein glycosylation in yeast. Annu Rev Biochem 56, 915-944.
MacKinlay, A. G. \& Wake, R. G. (1971). $\kappa$-Casein and its attack by rennin (chymosin). In Milk Proteins, vol. 2, pp. 175-215. Edited by H. A. McKenzie. New York: Academic Press.

Murakami, K., Aikawa, J., Horinouchi, S. \& Beppu, T. (1993). Characterization of an aspartic proteinase of Mucor pusillus expressed in Aspergillus oryzae. Mol Gen Genet 241, 312-318.

Murakami, K., Aikawa, J., Wada, M., Horinouchi, S. \& Beppu, T. (1994). A Mucor pusillus mutant defective in asparagine-linked glycosylation. J Bacteriol 176, 2635-2639.

Pitts, J. E., Dhanaraj, V., Dealwis, C. G., Mantafounis, D., Nugent, P., Orprayoon, P., Cooper, J. B., Newman, M. \& Blundell, T. L. (1992). Multidisciplinary cycles for protein engineering: sitedirected mutagenesis and X-ray structural studies of aspartic proteinases. Scand J Clin Lab Invest 52, 39-50.

Salovuori, I., Makarow, M., Rauvala, H., Knowles, J. \& Käriäinen, L. (1987). Low molecular weight high-mannose type glycans in a secreted protein of the filamentous fungus Trichoderma reesei. Bio/Technology 5, 152-156.

Takegawa, K., Kawasaki, N., Iwahara, S., Yamamoto, Y., Tochikura, T., Mikami, B. \& Morita, Y. (1989). Primary structure of an $N$-linked sugar chain derived from glucoamylase of Rhizopus niveus. Biochim Biophys Acta 990, 98-100.

Tarentino, A. L., Plummer, T. H. J. \& Maley, F. (1974). The release of intact oligosaccharides from specific glycoproteins by endo- $\beta$ $\mathrm{N}$-acetylglucosaminidase H. J Biol Chem 249, 818-824.

Tomiya, N., Awaya, J., Kurono, M., Endo, S., Arata, Y. \& Takahashi, N. (1988). Analyses of $N$-linked oligosaccharides using a two-dimensional mapping technique. Anal Biochem 171, 73-90.

Tonouchi, N., Shoun, H., Uozumi, T. \& Beppu, T. (1986). Cloning and sequencing of a gene for Mucor rennin, an aspartic protease from Mucor pusillus. Nucleic Acids Res 14, 7557-7568.

Yamashita, T., Tonouchi, N., Uozumi, T. \& Beppu, T. (1987). Secretion of Mucor rennin, a fungal aspartic protease of Mucor pusillus, by recombinant yeast cells. Mol Gen Genet 210, 462-467.

Received 17 November 1997; accepted 8 January 1998. 